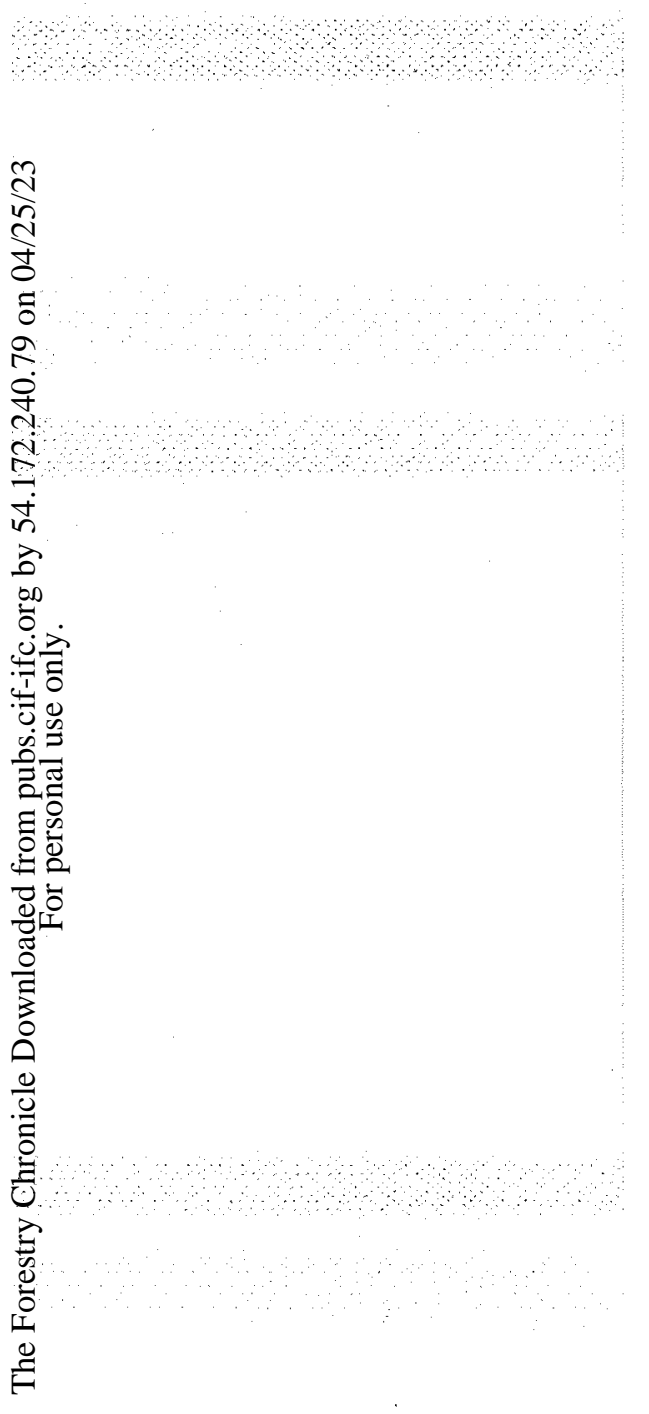

\title{
INSTITUTE'S WOODLOT COMMITTEES
}

\section{By A. KOROLEFF 1}

At its last annual meeting, the Canadian Institute of Forestry decided to concentrate its efforts in 1951, as fully as possible, on promotion of woodlot management in Canada; and the Standing Committee on Woodlot Management was requested to establish, only for that year, a Woodlot Management Promotion Committee, "to facilitate the required co-operative, co-ordinated effort".

That national committee was duly organized, under the capable chairmanship of J. L. Van Camp, General Manager of the Canadian Forestry Association. Its performance has been excellent and, of course, it will be reported on specifically by its chairman.

The relationship between the two committees on woodlot management has been very simple: After establishing the Woodlot Management Promotion Committee, the standing committee stepped aside and, as a group, has practically stood still, not to duplicate the effort and thus, possibly, confuse the issue. Some members of the standing committee were, however, appointed also on the temporary committee, and the chairman of the latter has been acting as the secretary of the first committee.

The organization of the Woodlot Management Promotion Committee unavoidably took considerable time so that its first meeting could be held only in the middle of February, and some regional groups started functioning even later. Considering the importance and magnitude of the objectives of that committee, it has had as yet too short a time fully to develop and to carry out its program, though a very good start has certainly been made. It would be a great pity if this highly useful committee were to end its life at the end of this year-at a time when its activities will only be getting into full stride.

I believe that at the coming annual meeting of the Institute the two committees dealing with woodlot management should be amalgamated, as to their functions, into a Standing Committee on Woodlot Management Promotion; and that the emphasis that has been placed by the Institute on that promotion work during 1951 should be extended into the future for as long as this will be needed.

In addressing the Institute at its last annual meeting, I suggested that this year, "through the joint effort of those concerned, plans be established for the required follow-up action--for continuous co-ordinated and effectual promotion of woodlot management in Canada on a national basis by an appropriate agency that can adequately cope with this need"-after 1951. I thought at the time that the Canadian Forestry Association might wish and be able to assume that responsibility, if it could be placed in a strong enough position for that function, through greater support and funds. The possibilities of that, I believe, have increased considerably. While the Canadian Forestry Association was formerly not very active in woodlot management promotion, last April it decided to devote to this one issue about half of its total funds and efforts, acting in co-opevation with the other agencies. That is a significant forward step.

1. Chairman, Standing Committee on Woodlot Management, Canadian Institute of Forestry. 
This year there have been some other indications that the needs of woodlot management in Canada are receiving more attention in some quarters than they used to. For example, a highly constructive move to tie up wood purchase from woodlots, by industrial companies, with clearcut provisions for sound management of these forests has been outlined recently by $R$. $G$. Belcher. ${ }^{2}$ The acceptance and implementation of such a plan by wood-using industries would undoubtedly do much good.

2. Canadian International Paper Company, Montreal. The title of Mr. Belcher's paper is "Small Woodlot Program". 